\title{
Participation in Forest Management Practices, Livelihood Diversification and Welfare of Forest Dwellers in Gambari Forest Reserve, Oyo State, Nigeria
}

\author{
Abimbola O. Adepoju ${ }^{1, a, *}$, Ifeoluwa O. Opadiran ${ }^{1, b}$ \\ ${ }^{1}$ Department of Agricultural Economics, Faculty of Agriculture, University of Ibadan, Oyo State, Nigeria \\ *Corresponding author \\ A R T I C L E I N F A B S T R A C T \\ Research Article \\ The management of forests, a source of livelihood in Nigeria, especially in the rural areas has \\ received little attention in recent times. As a result, most of the forest dwellers who depend on these \\ forests for survival are poor and are beginning to diversify their livelihood into off and non-forest \\ activities as a relevant source of income. This study assessed participation in forest management \\ Received : 22/06/2020 \\ Accepted : 26/09/2021 \\ practices, livelihood diversification and, the welfare of forest dwellers in Gambari Forest Reserve, \\ Oyo State, Nigeria. Primary data, collected from 121 respondents using a multistage sampling \\ Procedure were analyzed employing Descriptive Statistics, Logit, Tobit, and Ordinary Least \\ Squares model. The decision to participate in forest management practices was significantly linked \\ to gender, age, and membership in a forest association. Also, participation in forest management \\ practices, gender, age, and credit accessibility significantly influenced livelihood diversification \\ Keywords: \\ Forest Management Practices \\ Participation \\ Tobit \\ Livelihood Diversification \\ Welfare \\ positively while farm size and monthly income had negative effects. The welfare of forest dwellers \\ was found to be positively influenced by being a married indigene, having access to credit, \\ participation in forest management practices, livelihood diversification, and monthly income while \\ age, education, and market distance from homestead negatively affected the welfare of forest \\ dwellers.
}

\section{Introduction}

Forests are a predominant part of the earth's ecosystem, widely distributed across the globe. Specifically, it accounts for $75 \%$ and $80 \%$ of the gross primary productivity of the earth's biosphere, and plant biomass respectively (FAO, 2002). Human society and forest influence each other both positively and negatively (World Bank, 2002). The importance of the forest as a resource can never be over-emphasized due to its contribution to rural livelihood, poverty, welfare and inequality eradication, maintenance of ecological stability and biodiversity as well as the promotion of socio-cultural cohesion in the rural niche (Yogesh, 2014). The management of forests, through the participation of people in forest management practices (FMPs), is therefore very pertinent for sustainable development. These FMPs activities include pre-harvest planning, streamside management zone, forest wetlands protection, timber harvesting, re-vegetation, fire management or control, forest chemical management, reforestation, wildlife production, logging economics, soil protection, forest regeneration, clean up measures at logging sites, sustainable forestry, and control of forest vegetation. Participation in forest management practices contributes to a household's livelihood through its different components which include capabilities, assets, and activities. Thus, participation in FMPs should have a significant effect on livelihood diversification and rural household welfare. However, those who perceived that income generated through participation in FMP cannot meet their needs; diversified into farm, off-farm, and nonfarm livelihood activities to improve their welfare (Ellis, 2000).

A review of participation in FMPs has revealed that participation of households is influenced by age, marital status, household size, educational level, age of the head of the household, farm size, and forest distance (Dolisca et al. 2006; Soumyendra and Krishanu, 2010; Josephine et al. 2016; and Wambugu et al. 2017). However, most of the studies did not examine the effect of participation of forest dwellers in FMP on livelihood diversification and welfare of rural households in Nigeria. There has been limited research on the comparative assessment of participation in forest management practices and its effect on local community livelihoods and welfare. Development programs initiated in the past were designed to achieve sustainable forest growth through increased forest productivity and maximization of forest management 
efficiency but little attention has been paid to involvement in FMPs and its relationship to livelihood diversification and welfare of forest dwellers. The objective of this study is to examine the level of participation in forest management practices and the extent of livelihood diversification among the forest dwellers, the factors influencing household participation in FMP, the effect of participation in FMP on livelihood diversification of forest dwellers and the effect of livelihood diversification on the welfare of forest dwellers in Gambari Forest Reserve, Oyo State. This study has implications for potent policies for sustainable livelihoods and improved welfare of forest dwellers in Oyo State and by extension other forest communities in developing countries.

\section{Materials and Methods}

The study was carried out in Gambari Forest Reserve in Oyo State, Nigeria, formerly known as Ibadan District Native Authority Forest Reserve (IDNAFR). It lies between Latitude $07^{\circ} 25^{1} \mathrm{~N}$ and longitude $3^{\circ} 53^{1} \mathrm{E}$. The patches of the IDNAFR were consolidated into the present Gambari Forest reserve with a total landmass of 100,000ha in 1953 (Bakare, 2007). The majority of the dwellers are subsistence farmers cultivating arable crops like maize, cassava, etc. More importantly, the reserve provides raw materials for pulp and paper production and has an annual rainfall of $1140 \mathrm{~mm}$, mean temperature of $26.4^{\circ} \mathrm{C}$, and mean annual relative humidity of above 50\%. (Dept. of Forestry, Oyo State Ministry of Agric., Nat. Res. and Rural Devt, 2010).

The study relied on primary data. For equal representation, five zones were randomly selected out of the seven zones that constituted the reserve area and thirty respondents were randomly selected from each of these zones to make up a total of 150 respondents. However, only 121 respondents provided complete information, thus, constituting the sample size used for this study. Information collected include socio-economic characteristics of respondents such as age, marital status, primary occupation, level of education, household size, household income amongst others. Also, data collected include types of forest management practices, the various livelihood activities, and their monthly expenditure. A major challenge to the data collection was the valuation of the monthly food and non- food expenditure alongside income generated as the respondents do not keep records and they, therefore, depended on memory recall.

For the determination of the level of forest dwellers participation in FMPs and their extent of livelihood diversification, a participation index and diversification index were estimated respectively based on the number of types of forest management practices respondents participated in and the share of each livelihood activities engaged in the household.

$$
\text { FMP }=\frac{\text { Number of FMPs participated in }}{\text { Total number of FMPs }}
$$

Following and slight modification of the index of participation by Singhal and Rishi, 2003 and Solomon et al. 2017.

$$
\mathrm{HI}=\sum_{\mathrm{i}=1}^{\mathrm{n}} \mathrm{S}_{\mathrm{i}}^{2}
$$

Where, $\mathrm{n}$ denotes the number of livelihood activities and $\mathrm{Si}$ represents the share of each livelihood activity $\mathrm{i}$ in the household following Sharma, 2008; Khatun and Roy, 2016 and Kassie, 2017. The value would vary from 0 to 1. The index value is zero when there is a full specialization, and reaches one as the level of diversification increases.

\section{Factors influencing participation in Forest Management Practices}

Logistic regression is used to predict a categorical (usually dichotomous) variable from a set of predictor variables (Wuensch, 2014). It is based on cumulative logistic probability and is usually employed if the predictor variables are a mix of continuous and categorical variables and/or if they are not nicely distributed. Notably, logistic regression makes no assumptions about the distributions of the predictor variables (Wuensch, 2014). For logistic regression, the predicted dependent variable is a function of the probability that a particular subject will be in one of the categories. The Logit model was used to determine factors influencing participation in this study because of its computational simplicity in calculating the choice probabilities that are expressible in analytical form. However, the main limitation of this model is the independence of irrelevant alternatives probability which states that the ratio of the probability of choosing any two alternatives is independent of the attributes of any other alternatives in the choice set.

Following Maddala (1992), Greene (2008) and Gujarati (2004) the logistic distribution for the probability estimation of these factors follows a binary choice model and as such, the model as presented below can be specified as:

$$
\mathrm{P}_{\mathrm{i}}=\frac{1}{1+\mathrm{e}^{\mathrm{zi}}}
$$

Where, Pi is the probability of occurrence of events for the $i^{\text {th }}$ respondents and ranges from 0 to 1 . e represents the base of natural logarithms and $\mathrm{Zi}$ is the function of a vector of $n$ explanatory variables and expressed.

$$
\mathrm{Z}_{\mathrm{I}}=\beta_{0}+\sum \beta_{1} \mathrm{X}_{1}
$$

Where:

$\beta_{0}=$ intercept

$\beta_{1}=$ vector of unknown slope coefficients.

The relationship between $\mathrm{P}_{\mathrm{i}}$ and $\mathrm{X}_{\mathrm{i}}$, which is non-linear, can be written as follows:

$$
P_{i}=\frac{1}{1+e^{(\beta 0+\beta 1 X 1+\cdots \ldots \ldots \beta n)}}
$$

The slopes tell how the log-odds in favor of making a choice rather than other as independent variables change. If $\mathrm{P}_{\mathrm{i}}$ is the probability of an event occurring, then it follows that $1-\mathrm{P}_{\mathrm{i}}$ represents the probability of it not occurring and it can be written as:

$$
1-\mathrm{P}_{\mathrm{i}}=\frac{1}{1+\mathrm{e}^{-\mathrm{zi}}}=\mathrm{P}_{\mathrm{I}}=\frac{\mathrm{e}^{\mathrm{zi}}}{1+\mathrm{e}^{-\mathrm{zi}}}=\mathrm{P}_{\mathrm{I}}=\frac{1}{1+\mathrm{e}^{\mathrm{zi}}}
$$
gives:

Dividing equation (3) by equation (6) and simplifying

$$
\frac{\mathrm{P}_{\mathrm{i}}}{1-\mathrm{P}_{\mathrm{i}}}=\frac{1+\mathrm{e}^{\mathrm{zi}}}{1+\mathrm{e}^{-\mathrm{zi}}}=\mathrm{e}^{\mathrm{zi}}
$$


Equation (7) indicates simply the odd-ratio in favor of adopting the technologies. It is the ratio of the probability that a respondent will participate in FMP to the probability that he will not participate in FMP. Finally, the logit model is obtained by taking the logarithm of equation (5) as follows;

$$
L_{I}=\frac{P_{i}}{1-P_{I}}=Z_{I}=\beta_{0}+\beta_{1} X_{1}+\ldots \ldots \ldots \ldots+\beta_{n} X_{n}
$$

Where $\mathrm{L}_{\mathrm{i}}$ is the $\log$ of the odds ratio, which is not only linear in $\mathrm{X}$ but also linear in the parameters: Thus, if the stochastic disturbance term $\mathrm{U}_{\mathrm{I}}$ is taken into account, the logistic model becomes:

$$
\mathrm{Z}_{\mathrm{I}}=\beta_{0}+\beta_{1} \mathrm{X}_{1}+\ldots \ldots \ldots \ldots \ldots \ldots+\beta_{\mathrm{n}} \mathrm{X}_{\mathrm{n}}+\mathrm{U}_{\mathrm{I}}
$$

The Effect of Participation in Forest Management Practices on Livelihood Diversification

The effect of participation in FMPs on livelihood diversification was estimated using the Tobit model, following Ayantoye et al. 2017 and Solomon et al. 2017. An index was generated following the Herfindahl diversification index (Livelihood Diversification IndexLDI) which ranges from 0 to 1 (Sharma, 2008; Khatun and Roy, 2016 and Kassie, 2017). The index moves towards zero $(\mathrm{LDI}=0)$, with complete specialization into forestry and diversification into only one other activity exists. Whereas, where the number of livelihood diversification activities increases, LDI approaches 1 . It can be classified as follows:

0 to Mean of LDI means a low level of diversification, above the mean LDI, is categorized as a high level of diversification and between mean and standard deviation of LDI is medium diversification level. LDI is used as the proxy for livelihood diversification and serves as the dependent variable in the model.

The Tobit model is specified as;

$$
\mathrm{Y}=\mathrm{Y}=\beta \mathrm{Xi} \mathrm{fi}^{*}=\beta \mathrm{Xi}+\mathrm{Ui}>\mathrm{Ti}
$$

Where $U_{i}$ is normally distributed with zero mean and constant variance, $\mathrm{Xi}$ is the vector of explanatory variables and $\beta$ s are the coefficients to be estimated. The model can be transformed as thus;

$$
\mathrm{Y}_{\mathrm{I}}=\beta_{0}+\beta_{1} \mathrm{X}_{1}+\mathrm{U}_{\mathrm{I}}
$$

This can be explicitly rewritten as:

$$
Y=\beta_{0}+\beta_{1} X_{1}+\beta_{2} X_{2}+\beta_{3} X_{3}+\beta_{4} X_{4}+. .+B_{n} X_{n}+e_{i}
$$

\section{Ordinary Least Squares Model}

The OLS regression model estimated the effect of participation in FMPs on the welfare of forest dwellers. The linear form was used because it was the lead equation. The explanatory variables used were from literature including gender, age, household size, education level, marital status, livelihood diversification index, farm size, and market distance. Per Capita Expenditure (PCE) was used as a proxy for welfare. The basic OLS model is specified as follows following Babatunde and Qaim, 2009:

\section{Implicitly}

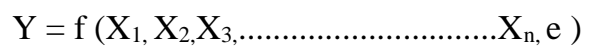

Explicitly, four functional forms were estimated to select the lead equation. These are:

Linear Function as;

$$
\mathrm{Y}=\beta_{0}+\beta_{1} \mathrm{X}_{1}+\beta_{2} \mathrm{X}_{2}+\ldots \ldots \ldots \ldots+\beta_{\mathrm{n}} \mathrm{X}_{\mathrm{n}}+\mathrm{e}_{\mathrm{i}}
$$

Semi log Function as;

$$
\mathrm{Y}=\beta_{0}+\beta_{1} \ln \mathrm{X}_{1}+\beta_{2} \ln \mathrm{X}_{2}+\ldots \ldots \ldots+\beta_{\mathrm{n}} \ln \mathrm{X}_{\mathrm{n}}+\mathrm{e}_{\mathrm{i}}
$$

Exponential Function as;

$$
\operatorname{LnY}=\beta_{0}+\beta_{1} X_{1}+\beta_{2} X_{2}+\ldots \ldots \ldots \ldots+\beta_{n} X_{n}+e_{i}
$$

Double Log Function as;

$$
\operatorname{LnY}=\beta_{0}+\beta_{1} \ln X_{1}+\beta_{2} \ln X_{2}+\ldots \ldots+\beta_{n} \ln X_{n}+e_{i}
$$

where, $\beta 0=$ constant term $e_{i}=$ Error term assumed to have normal distribution with zero mean, and constant variance i.e. e $\sim \mathrm{N}(0,1)$ and $\mathrm{E}(\mathrm{ei}, \mathrm{ej})=0 \mathrm{ij}$.

The description of model variables is presented in Table 1.

Table 1. Definition of model variables

\begin{tabular}{l|l}
\hline Variables & Definitions \\
\hline Gender of respondents & $(1=$ If male, $0=$ if Otherwise $)$ \\
Age of respondents & Age of respondents as at last birthday in years \\
Marital Status & Marital Status of respondents $(1=$ married, $0=$ if Otherwise $)$ \\
Household Size & Number of people living in the household \\
Educational Status & Educational level of respondents $(1=$ Primary, $0=$ if Otherwise $)$ \\
Farm Size & Land size exploited by the respondents for farming in Hectares \\
Residential Status & Residential Status of respondents $(1=$ If Indigene, $0=$ if Otherwise $)$ \\
Access to Credit & Respondents Accessibility to Credit $(1=$ if Yes, $0=$ if Otherwise $)$ \\
Forest Distance & Distance of the homestead to the forest in kilometers \\
Market Distance & Distance of homestead to market in kilometers \\
Membership & Whether a respondent belongs to a forest-related association or not $(1=$ if Yes, $0=$ if Otherwise $)$ \\
Monthly Income & Monthly income of respondents in Naira \\
FMP Participation & Whether respondents participated in FMPs or not $(1=$ If Yes, $0=$ if Otherwise $)$ \\
Livelihood Diversification Index & Index constructed from livelihood activities \\
\hline
\end{tabular}




\section{Results and Discussion}

The various types of forest management practices were divided into four major categories which include: production (regeneration, nursery practices, wildlife production, non-timber production, and reforestation), protection (soil protection, forest wetlands protection, and forest guards), economic (pre-harvesting planning, sustainable forestry, and timber harvesting) and control management (forest chemical management, fire control, clean up measures at logging sites, and streamside management). The FMP participation index shows that production forest management practices were the most participated in while control management practices were the least participated in by the forest dwellers.
Also, the extent of livelihood diversification of forest dwellers was moderate with at least four livelihood activities.

\section{Factors Influencing Participation of Forest Dwellers in Forest Management Practices}

The factors influencing the participation of forest dwellers in forest management practices are identified in Table 2. The chi-square value of 104.12 of the logit model is statistically different from zero at the one percent level of significance. Thus, implying the goodness of fit of the estimated model.

Table 2. Factors influencing participation of forest dwellers in forest management practices

\begin{tabular}{|c|c|c|c|}
\hline Variables & $\mathrm{dy} / \mathrm{dx}$ & Standard error & Z-Value \\
\hline Gender & $-0.181 * *$ & 1.036 & -2.55 \\
\hline Age & $-0.255^{*}$ & 0.036 & -1.89 \\
\hline Marital status & $0.126 * *$ & 1.051 & 2.35 \\
\hline Household size & $0.179 * *$ & 0.256 & 2.12 \\
\hline Educational status & 0.841 & -0.060 & -0.004 \\
\hline Farm size & 0.020 & 0.271 & 1.11 \\
\hline Indigene & $0.351 * *$ & 0.807 & 2.02 \\
\hline Credit accessibility & -0.017 & 0.751 & -0.33 \\
\hline Forest distance & 0.005 & 0.072 & 1.10 \\
\hline Market distance & -0.002 & 0.078 & -0.31 \\
\hline Forest association & $0.334 * * *$ & 1.710 & 3.68 \\
\hline Total income & $0.064 * * *$ & 0.021 & 2.99 \\
\hline
\end{tabular}

Log Likelihood = -28.772074; LR chi-square (12) = 104.12; Prob > chi2 = 0.0000; Pseudo R2 = 0.6441; Logistic model for participation in forest management practices security, goodness-of-fit test; Number of observation $=121 ; *$, ** and *** refer to statistical significance at 10,5 and $1 \%$

The effect of gender on participation in FMPs by forest dwellers was negative at $(\mathrm{P}<0.05)$. Specifically, being a male forest dweller decreased the likelihood of participating in FMPs by 0.181 . This implies that female forest dwellers participated more in FMPs. This finding thus corroborates that of Getacher and Tafere (2013) but contradicts the findings of Josephine et al. (2016) where a positive relationship existed between gender and participation in forest management practices.

Also, age had negative effects implying that a year increase in the age of forest dwellers decreased the likelihood of participation in FMPs by 0.255 . In other words, younger forest dwellers were more likely to participate in forest management practices. This might be connected to the fact that they are in their productive age and are better able to harness and utilize their energies for sustainable and productive ventures (Dolisca et al., 2006). Furthermore, a positive relationship existed between marital status $(\mathrm{P}<0.05)$ of forest dwellers and their participation in FMPs. Specifically, being married increased the likelihood of participation in FMPs by 0.126 .

Also, a member increase in the household size of a forest dweller by one member increased the likelihood of participation in FMPs by 0.179. Conversely, forest dwellers with a smaller household size tend to participate less in the FMP activities. This could be because smaller households have fewer demands for forest products and so they participate less in forest management than the larger households. Thus, in line with the findings of Parasada (2002), Chhetri et al. (2013) and Dolisca et al. (2006) who also reported that forest dwellers with larger household sizes are more likely to participate in FMPs. Expectedly, the positive relationship between the residential status of forest dwellers $(\mathrm{P}<0.05)$ and their participation in FMPs showed that being an indigene of the forest community increased the likelihood of participation in FMPs by 0.351 . This could be owing to the social inclusion and ease of access to the forest enjoyed by indigenes relative to nonindigenes. Also, being a member of a forest-related association increased the likelihood of participation in FMPs by 0.334 . This is expected as forest associations afford members benefits such as access to credit, information on price amongst others, consequently making them participate more in FMPs.

In the same vein, monthly income $(\mathrm{P}<0.01)$ of forest dwellers positively influenced their participation in FMPs. The marginal effect result revealed that a naira increase in income from the forest products increased the likelihood of participation in FMPs by 0.064 . This could be because of the economic benefits derived which encouraged participation. This finding supports those of Getacher and Tafere (2013), Agrawal and Chhatre (2006), and Dolisca et al. (2006).

\section{Effect of Participation in FMPs on Livelihood} Diversification of Forest Dwellers

The result of the Tobit model estimated to obtain the effect of participation in FMPs and other factors on livelihood diversification is presented in Table 3 . The chisquare value of 75.41 was significantly different from zero at a $1 \%$ level of significance, an indication of the goodness of fit of the model. Further, out of the six variables that 
significantly influenced livelihood diversification, gender, age, access to credit, and participation in FMPs by forest dwellers positively influenced livelihood diversification, while farm size and monthly income had negative effects.

Specifically, the coefficient of gender $(\mathrm{P}<0.10)$ was statistically different from zero and positively related to livelihood diversification. This implies that being a male increased the likelihood of livelihood diversification by 0.056 . This could be because men have more access to employment outside the home while women are most often, apart from their main source of livelihood, also engaged in other time-consuming household activities which affords them limited time for diversification. This finding supports that of Beyene (2008) and Ahmed et al. (2018). In addition, the age of forest dwellers $(\mathrm{P}<0.01)$ positively influenced livelihood diversification. This implies that a year increase in the age of forest dwellers increased their likelihood of livelihood diversification by 0.003 . In other words, younger forest dwellers are less likely to diversify their livelihood relative to older ones. This could be the case where older farmers have more access to information on other income sources, thus corroborating the findings of Barrett and Reardon (2001) and contradicting the findings of Kassie (2013). Similarly, credit accessibility was positively significant $(\mathrm{P}<0.01)$ which implies that having access to credit increased the likelihood of livelihood diversification of forest dwellers by 0.09 , thus reiterating the important role credit plays in the diversification of livelihood by forest dwellers through opportunities accorded them to invest in other income sources. However, this finding contradicted that of Solomon (2017) whereby households with access to credit were 0.16 times less likely to diversify their livelihoods than those who did not have access to credit.

Interestingly, the coefficient of participation in FMPs (0.029) was statistically different from zero at $1 \%$ and as expected was positively related to livelihood diversification of the forest dwellers. This implies that participation in FMPs of forest dwellers increased their likelihood of diversifying their livelihood into forest-based small and cost-effective enterprises to increase their streams of income, which otherwise would not have been known to them if they had not participated. This finding clearly shows the significant role that forest resources play in the rural economy in terms of the provision of alternative sources of jobs and incomes often needed to augment household income.

On the contrary, the result showed that farm size $(\mathrm{P}<0.01)$ was negatively related to livelihood diversification. In light of this, a hectare increase in the farm size of forest dwellers decreased their likelihood of diversifying their livelihood by 0.035 . This implies that households with large farm sizes take full advantage of the size of their farm, harness all their resources for increased productivity and by extension increased farm income ceteris paribus and thus diversify less while those with small farm holdings are likely to diversify their livelihoods to have other streams of income to augment household income. This result corroborates the findings of Yenesew et al. (2015) but is contrary to the findings of Kebede et al. (2014) who reported livelihood diversification was positively influenced by total farm size cultivated by the sampled households.

Also, livelihood diversification was negatively influenced by monthly income (Naira) of forest dwellers $(\mathrm{P}<0.01)$. This implies that a naira increase in the monthly income of forest dwellers decreased the likelihood of livelihood diversification by 0.01 . This is because increased income from a productive enterprise incentivizes against diversification into other ventures with uncertain streams of income.

\section{Effect of Livelihood Diversification on the Welfare of Forest Dwellers}

The effect of livelihood diversification and other factors on the welfare of the forest dwellers is identified in Table 4 . The F-value of 4.15 was significant at $1 \%$ showing the goodness of fit of the model. Also, the $\mathrm{R}^{2}$-value estimated to be 0.57 implied that $57 \%$ of the variation in PCE (Log of per capita expenditure was used as a proxy for welfare) of forest dwellers was explained by the regressors captured in the model. Age, level of education, and distance from homestead to the market negatively influenced the welfare status of forest dwellers. On the other hand, marital status, indigene status, participation in FMP, access to credit, and livelihood diversification had positive effects.

Table 3. Effect of participation of forest dwellers in FMP on livelihood diversification

\begin{tabular}{l|ccc}
\hline \multicolumn{1}{c|}{ Variable } & $\mathrm{dy} / \mathrm{dx}$ & Standard Error & $\mathrm{t}$-value \\
\hline Gender & $0.056 *$ & 0.028 & 1.96 \\
Age & $0.003 * * *$ & 0.001 & 3.08 \\
Marital status & -0.028 & 0.033 & -0.84 \\
Household size & -0.003 & 0.008 & 0.37 \\
Educational status & 0.049 & 0.033 & 1.50 \\
Primary occupation & 0.005 & 0.050 & 0.09 \\
Farm size & $-0.035 * * *$ & 0.002 & -4.46 \\
Residential status & -0.024 & 0.031 & -0.78 \\
Access to credit & $0.090 * * *$ & 0.032 & 2.82 \\
Forest distance & -0.003 & 0.003 & -1.22 \\
Market distance & 0.004 & 0.003 & 1.29 \\
FMPs Years of experience & 0.002 & 0.002 & 1.06 \\
FMPs Participation & $0.029 * * *$ & 0.005 & -5.44 \\
Forest association & -0.059 & 0.044 & -1.36 \\
Total income & $-0.014 * * *$ & 0.002 & -5.36 \\
Cons & $0.783^{* * *}$ & 0.075 & 10.39 \\
\hline
\end{tabular}

Log Likelihood $=56.43164 ;$ LR chi-square $(15)=75.41 ;$ Prob > chi2 $=0.0000 ;$ Pseudo R2 $=0.1135$; Tobit model for effect of participation in FMP on livelihood diversification, goodness-of-fit test; Number of observation $=121 ; * * *$ and $* * *$ refer to statistical significance at 10,5 and $1 \%$ 
Table 4. Effect of livelihood diversification on welfare of forest dwellers

\begin{tabular}{|c|c|c|c|}
\hline Variables & Coefficients & Standard error & t-value \\
\hline Gender & -0.016 & 0.021 & -0.80 \\
\hline Age & $-0.046^{* *}$ & 0.022 & -2.05 \\
\hline Marital status & $0.042 *$ & 0.024 & 1.76 \\
\hline Household size & -0.043 & 0.614 & -0.07 \\
\hline Education level & $-0.062 *$ & 0.330 & -1.88 \\
\hline Primary occupation & 0.029 & 0.036 & 0.82 \\
\hline Farm size & 0.065 & 0.062 & 1.05 \\
\hline Indigene & $0.043 *$ & 0.022 & 1.89 \\
\hline Participation FMPs & $0.066 *$ & 0.035 & 1.89 \\
\hline Credit Accessibility & $0.039 *$ & 0.021 & 1.84 \\
\hline Forest distance & -0.049 & 0.194 & -0.26 \\
\hline Market Distance & $-0.058 * *$ & 0.025 & -2.35 \\
\hline FMP years of experience & 0.025 & 0.096 & 0.26 \\
\hline Member Forest association & -0.039 & 0.031 & -1.24 \\
\hline LDI & $0.189 * * *$ & 0.063 & 2.99 \\
\hline Cons & $0.032 * * *$ & 0.007 & 4.58 \\
\hline
\end{tabular}

$\mathrm{F}(15,105)=4.15 ;$ Prob $>\mathrm{F}=0.0000 ; \mathrm{R}$-squared $=0.5723$; Adj R-squared $=0.2827$; OLS model for effect of livelihood diversification on welfare, goodness-of-fit test; Number of observation $=121 ; * * *$ and $* * *$ refer to statistical significance at 10,5 and $1 \%$

The coefficient of residency status was positively related to the welfare status of the forest dwellers. This implies that being an indigene of the forest community improved welfare. This could be attributed to the fact that the cultural setting of the area allows indigenes to have better opportunities to benefit from the varying livelihood options provided by the forests relative to non-indigenes in the study area. Also, the participation of the forest dwellers in FMP was positively related to the welfare status of the forest dwellers. That is, participation in FMPs improved the welfare of the forest dwellers. This could be through an increase in income from participation in forest-related activities.

Furthermore, livelihood diversification was positively related to the welfare status of forest dwellers. This implies that diversifying livelihood improved the welfare of the forest dwellers. In other words, forest dwellers who were engaged in more than one livelihood activity had a higher level of welfare which can be attributed to having multiple streams of income to meet basic necessities. This, corroborates the submission of Babatunde and Qaim (2009) in which LDI had a positive effect on the welfare status of farming households. In the same direction, marital status positively influenced welfare, implying that being married improved welfare. This as expected could be the case if the spouse is working and contributes to household resources. Similarly, the result further revealed that access to credit by forest dwellers improved their welfare significantly at $1 \%$ level. This implies that having access to credit increased the likelihood that forest dwellers will have an improved welfare. This is not implausible as credit increases the capital available for investment thus, leading to increased income generation and consequently improved welfare status of the forest dwellers. This is in line with the findings of of Babatunde and Qaim (2009) who emphasized that access to credit improved the welfare status of farming households.

However, the coefficient of age was negatively related to the welfare status of the forest dwellers. This implies that younger forest dwellers have improved welfare relative to their older counterparts. This could be because younger forest dwellers are more likely to have varied streams of income from forest-related activities because of the rigors associated with such activities and other wage activities. This result however contradicts the findings of Akaakohol and Aye (2014) who reported a positive association between age and welfare status of farming households. Also, educational status negatively influenced the welfare of forest dwellers, indicating that having a low level of education decreased welfare. Being educated confers the ability to be able to make informed decisions on high income generating livelihood options which ultimately leads to improved welfare. This finding corroborates the findings of Adepoju and Obayelu (2013). Also, the distance from the homestead of forest dwellers to the nearest market which was used as a proxy for market access had a negative influence on welfare. In other words, the less access (greater distance) forest dwellers have to the market, the lower their welfare.

\section{Conclusion and Recommendations}

Participation in forest management has been recognized as a significant and essential part of the livelihood of forest dwellers. The study has shown that participation in forest management practices plays a pivotal role in the livelihood diversification and welfare of the forest dwellers. Being an indigene, membership of forest association, and enhanced income among other factors contributed to the likelihood of participation in forest management practices. Thus, adequate information and sensitization of forest dwellers by government and Non-governmental organizations (NGO's) on the benefits of participation and enhanced income generation from forest activities are key for increased participation. Also, the need to emphasize membership in the FMPs associations could play a significant and constructive role in forest protection, management, optimal use and sustainable development of forest. Participation in forest management practices and better accessibility to credit contributed to the diversified livelihood of forest dwellers. Expanding efforts at ensuring credit facilities to forest 
dwellers at reasonable and favorable terms, which could require a total revamp of the rural financial systems especially in terms of collateral requirements, and creating employment opportunities through participation in forest management practices for diversification of livelihoods is pertinent for improved welfare of the forest dwellers.

\section{References}

Adepoju AO, Obayelu OA. 2013. Livelihood Diversification and Welfare of Rural Households in Ondo State, Nigeria. Journal of Development and Agricultural Economics, 5 (12):482 489.

Agrawal A, Chhatre A. 2006. Explaining Success on the Commons: Community Forest Governance in The Indian Himalayas. World Development, 34:149-166.

Ahmed MT, Bhandari H, Gordoncillo PU, Quicoy CB and Carnaje GP. 2018. Factors affecting extent of rural livelihood diversification in selected areas of Bangladesh. SAARC Journal of Agriculture, 16(1):7-21.

Akaakohol MA, Aye GC. 2014. Diversification and farm household welfare in Makurdi, Benue State, Nigeria. Development Studies Research, 1 (1): 168-175.

Ayantoye KI, Amao JO, Fanifosi GE. 2017. Determinants of livelihood diversification among rural households in Kwara State, Nigeria. International Journal of Advanced Agricultural Research, 5: 82-88.

Babatunde RO, Qaim M. 2009. Patterns of income diversification in rural Nigeria: Determinants and Impacts. Quarterly Journal of International Agriculture, 48 (4): 305-320

Bakare J. 2007. Assessment of Crop Performance in a Taungya Age Series in Gambari Forest Reserve. An Unpublished Project submitted to the Department of Forest Resources Management. University of Ibadan. Pp 85.

Barrett CB, Reardon T, Webb P. 2001. Nonfarm income diversification and household livelihood strategies in rural Africa: concepts, dynamics, and policy implications. Journal of Food Policy, 26(4):315-331.

Beyene AD. 2008. "Determinants of Off-Farm Participation Decision of Farm Households in Ethiopia." Agrekon: Agricultural Economics Research Policy and Practice in Southern Africa, Journal of Agricultural Economics, 47 (1): 140-159.

Chhetri K, Johsen H, Konoshima M, Yoshimtota A. 2013. Community Forestry in the Hills of Nepal: Determinants of User Participation in Forest Management. Journal of Forest Policy Economics, 30:6-13.

Department of Forestry, Oyo State Ministry of Agriculture Natural Resources and Rural Development. 2010. https://oyostate.gov.ng/ministry-of-agriculture-naturalresources-and-rural-development/.

Dolisca F, Carter DR, McDaniel JM, Shannon DA, Jolly CM. 2006. Factors Influencing Farmers' Participation in Forestry Management Programs: A Case Study from Haiti. Journal of Forest Ecology and Management, 236:324-331.

Ellis F. 2000. The Determinants of Rural Livelihood Diversification in Developing Countries. Journal of Agricultural Economics, 51(2):289-302.

FAO 2002. Forest, Food Security and Sustainable Livelihoods. Food and AgriculturalOrganization of the United Nations, Rome, Italy. FAOSTAT 2002. Food and Agriculture Organisation Statistics. FAO, Rome

Getacher T, Tafere A. 2013. Explaining the Determinants of Community Based Forest Management: Evidence From Alamata. Ethiopia International Journal of Community Development, 1:63-70.
Greene WH. 2008. Econometric Analysis. (6th ed.). Pearson Prentice Hall. Upper Saddle River, New Jersey.

Gujarati D. 2004. Basic Econometrics. 4th Edition, McGraw-Hill, New York.

Josephine KM, Jayne M, Mutundu K, Mbaei M. 2016. Factors Influencing Level of Participation of Community Forest Associations in Management Forests in Kenya. Journal of Sustainable Forestry, 35 (3):205-216.

Khatun D, Roy BC. 2016. Rural livelihood diversification in West Bengal: Nature and extent. Agricultural Economics Research Review, 29 (2):183-190.

Kassie GW. 2013. Livelihood diversification and Sustainable land management: The case of North East Ethiopia. www.apu.ac.jp/media/library/thesis/_spring.html

Kassie GW. 2017. The Nexus between livelihood diversification and farmland management strategies in rural Ethiopia. Cogent Economics and Finance, 5(1): 1-16.

Kebede M, Haileselassie AG, Haile M, Luchia T. 2014. Livelihood diversification strategies among men and women rural households: Evidence from two watersheds of Northern Ethiopia. Journal of Agricultural Economics and Development, 3(2): 017-025.

Maddala GS. 1992. Introduction to Econometrics. Second Edition. Macmillan Publishing Company. New York.

Parasada RM. 2002. The Determinants of Rural Off Farm Employment in Two Villages of Andhra Pradesh (India).Sussex: Poverty Research Unit, University of Sussex.

Singhal R, Rishi P. 2003. Indicators of participation in joint forest management: An empirical analysis. A paper submitted to the XII World Forestry Congress, Quebec city, Canada. http://www.fao.org/3/XII/0511-B4.htm.

Sharma KR. 2008. Measuring economic diversification in Hawaii. Research and Economic Analysis Division (READ). Department of Business, Economic Development and TourismofHawaii.http://hawaii.gov/dbedt/info/economic/dat a_reports/EconDiversification/Economic_Diversification_R eport_Final\% 203-7-08 [1]. Pdf.

Solomon T, Muliluneh W, Feyera S. 2017. Forest Users' Level of Participation in a Participatory Forest Management Programme in South-Western Ethiopia. Journal of Forest Science and Technology, 13 (4): 164-173.

Soumyendra KD, Krishanu S. 2010. Status of Joint Forest Management in India: Socio-Economic Determinants of Forest Participation in a Dynamic Optimization Setting. International Journal of Social Forestry 3(2): 81-100.

World Bank, 2002. World Development Report 2000/2001: Attacking Poverty. Oxford University Press.

Wambugu EW, Gilbert GO, Kirui BK. 2017. Socioeconomic Factors that determine community participation in forest management and conservation of adjacent ecosystems: A case of Aberdare forest, Kenya. Journal of Ecology and the Natural Environment 9 (10): 165-176.

Wuensch T. 2014. The Use of Logistic Regression in Psychological Research. Journal of Social Behavior and Personality, 2: 35-39.

Yogesh R. 2014. Determinants of People's Participation in Forest Protection and Management: A study in Kaski, Nepal. Economic Journal of Development Issues, 17\&18 (1-2): 175186.

Yenesew SY, Eric NO, Fekadu B. 2015. Determinants of livelihood diversification strategies: The case of smallholder rural farm households in Debre Elias Woreda, East Gojjam Zone, Ethiopia. African Journal of Agricultural Research, 10:1998-2013. 